\title{
境の暴風とその規準氣壓 \\ 吉田余 三男
}

Critical Value of the Atmospheric Pressure for the Gale Waraing at Sakai.

$$
\text { by Yosao YOSIDA. }
$$

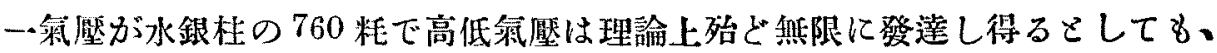
世界の最高記錄が 808 籷餘であり、低氣壓の最低記錄が 686 籷位で此間の美が120 籷であるが、地球が現狀で吾人が現世界に生存して居る此條件が激戀しない以上 は、其上地に暴風の襲及乘壓の限界を定さる事は突飛な栐で自ら何者から゙存在す る哉に若人得る。

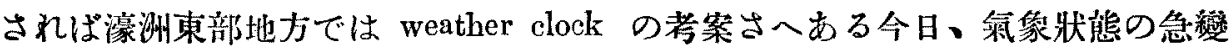

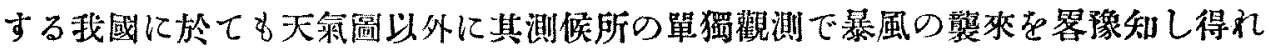
ば weather clock やギハベーッ氏の規隼風力の如くまで行かずとも重锤である。 少又我國今日の氣象事菜の組織では一日三回高低巣壓の位置を知り得るに過ぎな

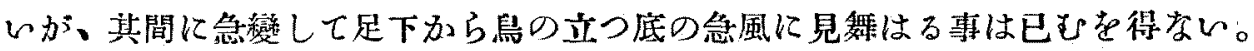

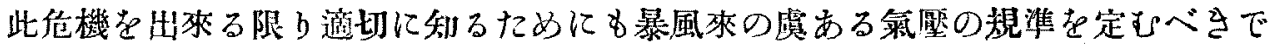

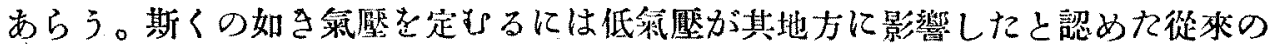
訅錄を探り、之を統計して決定するは最8簡明な方法だら5が、其手数の慗錎に して若し之を成したとせば其过遠を自嘲せざるを得ないし、同時に760粍を高低

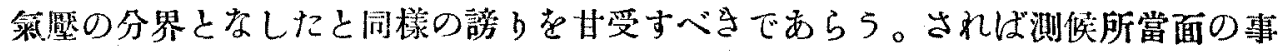

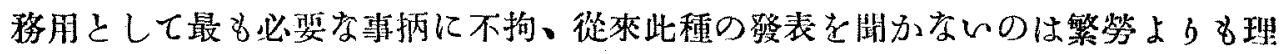
由は篎万後者にあつたか子知れないのみならず、多年間に經驗した最名高價なる 派酬として自ら得てものとし筐底に浇しあるにあらざるか。兔に触此種の發表は あるべくして余り見當らない。近頃山本氏は种戸の急風に就さ、双故朝倉氏は横 䟺の急栭に就き發表があつたが本交さは多少造つた點がある。

私が所謂規準氣筑を求むる必琶を痛切に感じ且又求め得ると信じた動機は、冬

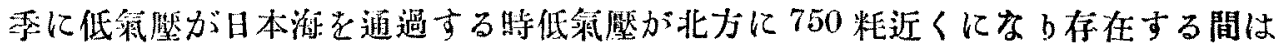




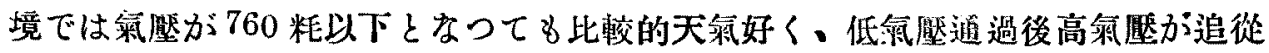

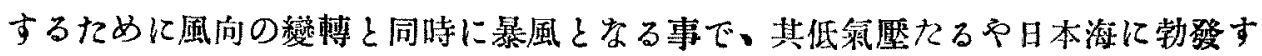
るものすあるが、(本誌昨年七月號德山氏論文參照) 又大陸で未だ低氣壓として の本能を發揮せず廣漠な淺さ低埭壓部であつねものが、不幸夜間(十八時後)に日 本海に進出して急に發達し暴風を㟟起することが多い。而もその變化發達は屡タ

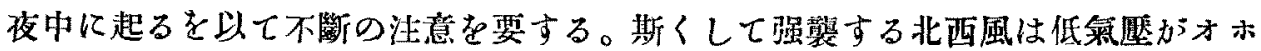

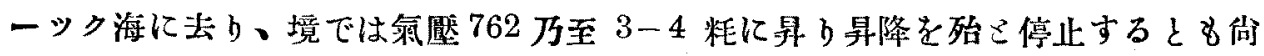

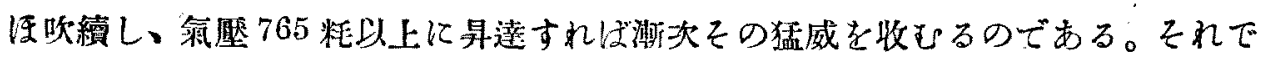
低氣壓が日本海北西方に存し、氮壓が急降して居るに不關風弱く好天氮を表し、 低氣壓が北東に移り高氣壓の急伸に件し急風瑧り天氮惡くなるが如さ特徵ある現 象は大陸高氯壓の發展に就さ海陸の配布其他の機棈が如何に巧妙子るか、將又高 低氣壓の間に伏在する因果關係が如何なるかを着目するに力强いるのであらねば 次ら奴。殊に職務執行に直面して緊要方るは因果つ約束を察知し以てその責務に

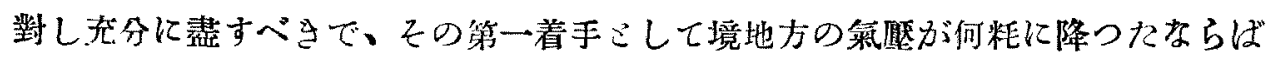
警戒すべさ戎にあり。

更に進んでは筑風及勃發低氯壓にして如何程に發澾しその進路は何くなるや、 又その機構に關しても研究すべさ事抦は多々あるる本交に於ては地方常面の問題 として境の氮㭫に就てのみ調查し後日研究の資料を得るに至らば第二第三の域に 入る゙の機會を得べく希望する次第である。

然らば規準は如何にして求さる哉と云ふに、近來觀测值の本均の意義及價值に 就さ色々論議されて居るが、此場合は鬼も看も觀測の累年平均を最子有意義のる のとし、夏重し利用して之を求定したのである。郎ち境の月本均氮娾と天津のそ

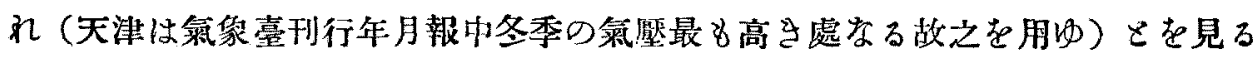

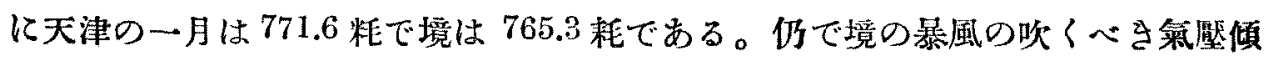
度は 0.9 籽(本誌大正六年四月號山田氏のShaw 氏公式より求めたるものに據る) であるから、天津方面から境方面に氮壓が遞減して、境に暴風の吹走する場合を 最子簡單に考へると、雨地間の傾度は約 14.4 精で、此 14.4 粍は境に暴風を䓯起す る限度と考へる。(此の取扱と方に就き可否の議諭は相當あるに違いるい第一に0. 
9 粔で强風になる假定は理論上可能なるる地上にては摩擦等あり。况や地形の影 響甚大なるるのあり。之等を度外視して問題の成立を期するは碩るきっつこしい ものであるが、爱では便宜此考人を以て進み、夫の成果方何の位規準の語に適應 し得るか在萑究したのである加ら之を諒と甘られ度に）故に今天津の一月の本均 氮壁は 771.6 粔である時は境に於ては771.6-14.4=757.2粔が此限度に相當するの である。然るに 771.6 粍は天津では高低の本均したもので天津附近の低壓の場合

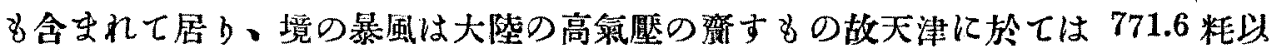

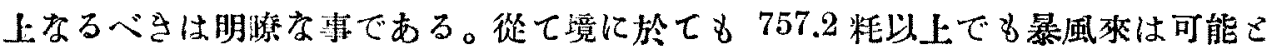
なる。然らばその以上の程度を求されば境の本均 765.3 籷の上に出づるは不可能 なるべく結局 $(765.3+757.2) / 2=761.3$ を以て所要の氣壓と定め得たのである。 之と同荄の手段を檴じて二、三、十一、十月等大陸に高氮壓の根元が占據する 期間は之を求定し得る。

上起の考へよb求め九る結果は一月 761,3 粔、二月 760.3 粔、三月 760.3 粔、十

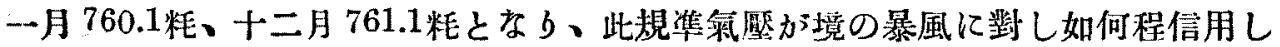
得るかを調查し次の表を得た。裴は入正七年より大正十一年まで五年間の結果で ある。

\begin{tabular}{|c|c|c|c|c|c|c|}
\hline & I月 & II 月 & III月 & XI月 & XII月 & 郭 \\
\hline 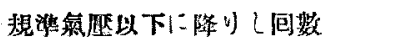 & 20 & 18 & 23 & 21 & 15 & 97 \\
\hline 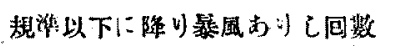 & $17(2)$ & $1.5(5)$ & $18(7)$ & $15(3)$ & $14(6)$ & $79(23)$ \\
\hline 規售まで降らず暴風ありし回数 & 5 & 10 & $7(1)$ & 2 & 10 & $34(1)$ \\
\hline 替㵏以下に降り暴風なっ・り (回残 & 3. & 3 & 5 & 6 & 1 & 18 \\
\hline
\end{tabular}

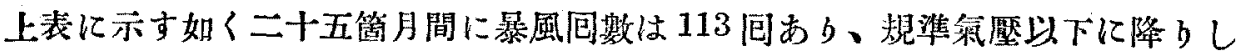

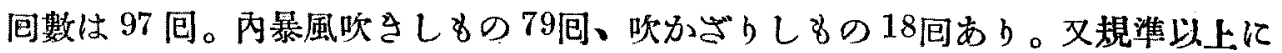

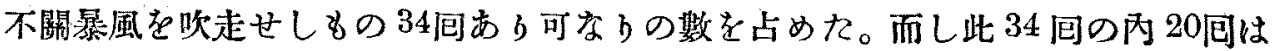
1ー2㭙間位の短時間强吹によるものである。又時に特别な過程を取つた高氣綮の ためのるあるか゚、一般に天氣模樣は左程惡くない方である。之に反して規準氯壓 以下に降り暴風なかりし回數の內には天氮惡く大雨が降つたのや、風速が8-9米 こ云ふるのが大部分を占めて居る事は釋朋するまでるない事で、此外測候所の位 置の缺點子可なり各值を左右するるの加あらら。括弧を附したのは烈風以上の国 數であるが、三月に 1 包規準以上で吹いて居るが23回中 1 间で三月は移動性高氮 
壓の來往繁からんとする時季で此例外は巳むを得むい。

翻つて之等各月の所定の示度に降 $b$ 初めて後幾時間にして暴風承るやは頗る興 味あり且つ最も知らんこ欲する處である。さらながら此は其時の氣曆配置に依り

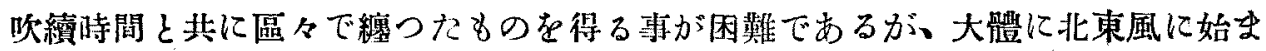
る場合は早隶する。次表は烈風以上と吹續時間四時間以上のるの時間刷にした のである。

$\begin{array}{ccccccccc}\text { 時 } & \text { 間 } & 0-4 & 5-8 & 9-12 & 13-16 & 17-20 & 21-24 & 24 \text { 以上 } \\ \text { 回 } & \text { 数 } & 7 & 10 & 9 & 9 & 5 & 2 & 7\end{array}$

之に哌れば5一-8時間が最多であるが、0-4時間の 7 回の內 3 包は北東風に始ま つたすのである。但し時間は六包觀測より得たもので其間に起つた時は按分して

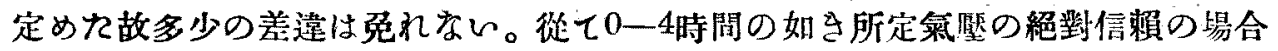
を想像する時は多少の不安を威すべさき幾分減少すへく、文他の計數と對比せば 必然のものなるかも知れない。

斯く冬季に於りる暴風來の規準氣壓を設定したが進んで他の時期のるのをる求 め得るとすれば便益を享くる事であらら。殊に秋季に颱風の方向㙛換に由る裝否 を考定するに有力な資料となる。依つて他の各月に就导前こ同樣に何處かを基本 として境と此較し之を探求せんとするのである。そして十月は多少實質を異にし て居るが大體は冬の氮壓配置と同型式であるから方法も之こ同じで求め得る。然 るに四、五月に至れば高壓部は全く本州方面を䁈し低壓部は滿洲西比利亞方面に あら、冬の方法を以て律するは不可能である。仍で此期間の最も氣壁の低さ長春 こ高壓部の境さより、冬と同方法で長春のそれと認ひべさものを求め、その数值と 長春自己との殘美を境より引さ之を決定した。六、七月は高壓部小篮原島方面に 固定するt以て、父島と境とに份り容易に求め得る。八月は北海道方面に九月は 本州に夫れ夫れ高壓部存在し、低歷部は兩月共南西諸岛より臺灣方面にある。然 るに雨月は颱風季で颱風は沖繩島附近で方向を囀換し、且つ奄美大島以南に颱風 彷徨す万間は殆どその影響は認め難さ故、境と名瀨とに依b四、五月に做と之を 求めた。其結果は次の如くで同期間の暴風四數等を合せ揭げれ。

之等を冬季のものと比較する時は多少遜色むるる全く無貲值のるのとは思人な 


\begin{tabular}{|c|c|c|c|c|c|c|c|c|}
\hline & IV月 & $\mathrm{V}$ 月 & VI月 & VII月 & VIII月 & IX月 & $\mathrm{x}$ 月 & 㭷 \\
\hline 规㴖氣壁以下!：降り (回数 & 20 & 19 & 15 & 10 & 10 & 11 & 17 & 102 \\
\hline 規华以下に隆り 風おりし回卙 & $17(2)$ & $14(5)$ & $9(2)$ & $9(4)$ & $9(4)$ & $7(2)$ & $7(1)$ & $72(20$ \\
\hline 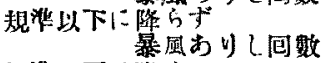 & 5 & $4(1)$ & 1 & 2 & 5 & $4(1)$ & 3 & $24(2)$ \\
\hline 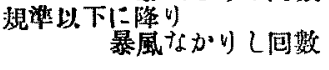 & 3 & 5 & 6 & 1. & 1 & 4 & 10 & 30 \\
\hline 筷 & 756.8 & 755.5 & 752.2 & 752.2 & 751.4 & 754.4 & 757.2 & \\
\hline
\end{tabular}

い。十月の規準氣壓以下に降 b暴風子かるし回數10は他を拔さ大となつれのは、 九月の高壓部は本州に掩留したるす斯月の高氮壓は大陸に占據するもの多く、依 つて天津の本均值を大ならしめれ。然れども大氣活動の中心は大洋よb大陸に還

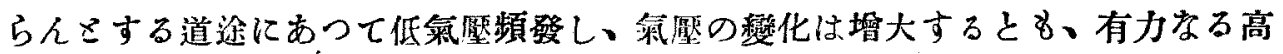
氣壓なさなめ一年を通じて最子本䇺なる月となり、他月と趣を異にした。之に反 して二月は所定氮壓以上にて暴風となつたもの10包あb。之は高氣暨、支那中部 より本邦に發展せんとする傾向著しく、天津学探用したるため境との本衡を得ず 過低となったのであるむいか。故に之等の月に於ては多少の手心を要する。所定 氣厴は一月に區切つて算出したが、精細を㘹む時は作圖法に依ら旬每か牛旬每に 求むる事む出來得る。然る時は表の數値はより以上の確率を得るであらら。

以上規準氣壓の名窂を使用したが嚴格なる解義を下す時は妥當ではないかる知

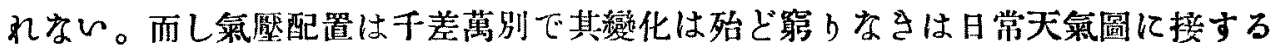
吾等同人の齊しく荻ずるすのであるが、此間に處して捕へ得る数值としての規準 氣捱は、以下の回數 199 の内 151 暴風吹き九るを除も、それ以上にて暴風來の问 數と以下にて來らざるし回數との差示10回の少數なるを見出し得るは今日の豫報

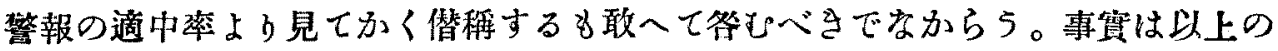
如くその効果を高調するに非ざるもその絕對確率73\%を得九るを考京れば勃發低 氣壓の發生等の場合に處して可なるの自信を以て當る事を得るを喜ひとするもの である。最後に附言したさは之等は踈荒且つ不備るる假定の下に、單なる因果の 約束と云ふ如き淺さ根柢に立脚したるを不洣をするすのであるが、資料にそしく 攻究に不便多さ余䧳の今日に於ては、よb以上に進み難く更正の機會恕せられ ん事を希望するるのである。 